\title{
SOME OBSERVATIONS ON THE OCCURRENCE OF AZOTOBACTER IN FINNISH SOILS
}

\author{
BY \\ Armi KaILA \\ University of Helsinki, Department of Agricultural Chemistry \\ Received 7th December 1953.
}

Azotobacter chroococcum, one of the most thoroughly investigated microorganisms, has been treated also in the rather scanty literature concerning the microflora of Finnish soils. And a striking fact is that the two scientists who have reported observations upon the occurrence of Azotobacter in our soils have come to contradictory results. Brenner (2) states that Azotobacter can be no common member of our soil populations, since he could find it only in two soil samples out of the two hundred tested ones. Svinhufvud (25), on the other hand, cultivated Azotobacter from all his four samples of forest soils, some of them markedly acid.

According to the present opinion $(11,18)$ Azotobacter chroococcum and the other species of this genus cannot play any important role in the nitrogen economy of soils, not even under more favourable conditions than those prevailing in our rather acid soils. Yet, it is of interest to study what is the truth of the distribution of this organism in Finnish soils, and if possible what are the factors affecting its occurrence.

An attempt to elucidate these problems was made in the present investigation. A number of soil samples representing different soil types were collected from various parts of the country and tested for the presence of Azotobacter species. For a more detailed study on the effect of the soil properties upon the development of Azotobacter chroococcum, samples collected from one farm were used, in order to eliminate the effect of the larger differencies in the climatic conditions. Some attention was also paid to the ability of the soil population to fix atmospheric nitrogen.

\section{Methods}

The occurrence of Azotobacter in the soil samples was studied by the method of CURIE (5) in which mannitol agar plates are inoculated by sprinkling soil granules upon the surface. The plates were incubated at $25^{\circ} \mathrm{C}$ for one week, and the azotobacter-like colonies isolated on mannitol agar slants. The identification was made by the microscope.

In order to study the possible presence of Azotobacter indicum in the samples inoculation was also performed on glucose agar plates and the incubation period prolonged 
Azotobacter was enriched in the soil samples by incubating in Petri dishes at $25{ }^{\circ} \mathrm{C}$ for two weeks $25 \mathrm{~g}$ of soil with an application of $0.2 \mathrm{~g}$ of calcium carbonate and $5 \mathrm{ml}$ of a solution that contained 12.5 per cent mannitol, 0,35 per cent dipotassium phosphate and a trace of sodium molybdate.

The occurrence of Clostridium species in the samples was examined in nitrogen-free glucose-phosphate solution inoculated with pasteurized soil suspension (7, p. 118). The presence of these organisms in the cultures was demonstrated by the formation of gas and by the microscopical study.

The test for the deficiencies in available calcium, potassium, and phosphorus in the soil was made by the method of SAckett and Stewart (20), but using glucose instead of corn starch. The pH-values of the soils were measured in water suspension (1: 2), the exchangeable calcium determined by the method of TU ORILA (26), the "available" phosphorus by the acetic acid method (12), and the total nitrogen content by the common Kjeldahl procedure.

For the estimation of the relative nitrogen-fixing power of the soils the mannitol-solution method was employed.

\section{Occurrence of Azotobacter in soil samples}

The agar plate method was chosen to show the presence or the absence of Azotobacter in the soil samples, because it was thought to offer some advantage as compared with the solution methods. CURIE (5) points out the fact that in solution cultures the activity of amoebae, the largely anaerobic conditions, and the formation of butyric acid and other organic acids may prevent the development of the typical Azotobacter film except in the presence of an abundant Azotobacter chroococcum flora. In addition, the agar plate method by CURIE (5) is simple, and the isolation of the organisms is easier than from the solution culture.

Of course no pure cultures of nitrogen-fixing organisms can be supposed to develop on the nitrogen-free mannitol agar from soil granules scattered over the surface. Yet, the cultures obtained were typical. The most predominant colonies were formed by colourless, slime producing bacteria, which according to a preliminary identification most probably were representatives of Agrobacterium radiobacter group. This organism is known to need very low amounts of fixed nitrogen, and it has been mentioned to be a common contaminant in Azotobacter isolates (23). Also it has been reported to be able to fix atmospheric nitrogen, although in a rather low degree $(22,23)$.

Even during a prolonged incubation the development of Azotobacter colonies could be demonstrated only from three of the fifty soil samples at first tested. The most abundant flora was obtained from a cultivated clay soil from Kauhajoki, in Southern Ostrobothnia. Its $\mathrm{pH}$ value was rather high, $\mathrm{pH}$ 6.58. The two other samples which contained Azotobacter so abundantly that colonies developed on the agar plates were taken from the same farm in Laukaa, in Central Finland. One of them was a sandy mull soil with a $\mathrm{pH}$ value of 6.40 , the other a silt soil with a lower $\mathrm{pH}$ value, $\mathrm{pH} 5.90$.

The presence of a vigorous Azotobacter chroococcum flora in these three soils could be proved also by Winogradsky's soil plaque method. After an incubation period of two days about 300 slimy, typical Azotobacter colonies were found on the surface of the Kauhajoki clay soil in the Petri dishes. The sandy mull from Laukaa developed about 50 colonies, and the slightly acid silt soil from Laukaa only about 
10 colonies. During prolonged incubation black pigment was formed in the colonies.

The results obtained from these tests are in accordance with the observations of BREnner (2) and quite clearly indicate that Azotobacter chroococcum is no common representative of the soil microflora in Finland. At least, its number in most of our soils must be extremely low.

The fact that Svinhufvud (25) and according to his report also FeHÉR could find Azotobacter chroococcum in all the acid forest soil samples examined can be explained if attention is paid to the low numbers of the organism in these soils. The total amounts of aerobic nitrogen-fixing organisms estimated by the dilution method did not exceed 1000 per gram of the soil, and the number of real Azotobacter-cells could be much lower.

It seemed to be of no use to continue this testing of soil samples collected from the various parts of the country. Instead of that a more detailed study was directed to the distribution of Azotobacter in the soils of the Laukaa farm from which the two Azotobacter samples originated. For this purpose samples were collected from various parts of this farm, all from cultivated soils.

Table 1 contains analytical data for these soil samples. The samples L 3 and L 5 represent the soils that gave positive Azotobacter tests. The sample L 25 was taken from the same area as the sample L 3. The agar plate tests for the presence of Azotobacter were performed both directly from the fresh soils and from the enriched samples. The $(+)$-mark means that Azotobacter colonies were found only occasionally and not in all duplicates.

Without the enrichment procedure Azotobacter chroococcum could be found only in five samples, and two of them contained it in a rather small amount. The enrichment, however, increased the Azotobacter flora in such a degree that colonies of the organism developed from ten of the twenty five samples tested by the agar plate method. This suggests that Azotobacter chroococcum probably is more common in our soils than the results of BRENNER (2) showed, but that its number even in a large part of the fertile soils is very low.

It is of interest to notice that if the $\mathrm{pH}$-values, the contents of exchangeable calcium, acetic-acid soluble phosphorus or total nitrogen are compared, the soils which gave a positive result in the test without any enrichment did not significantly differ from those in which no Azotobacter could be directly found. This appears from the following variation limits:

$\begin{array}{lcc} & \text { Azotobacter present } & \text { Azctobacter absent } \\ \mathrm{pH} & 5.83-6.40 & 4.75-7.82 \\ \mathrm{CaO} \% & 1.9-4.5 & 1.4-12.6 \\ \mathrm{P}_{2} \mathrm{O}_{5} \mathrm{ppm} & 5-102 & 4-108 \\ \mathrm{~N}^{0} \% & 1.7-3.4 & 1.8-7.8\end{array}$


Table 1. Presence of Azotobacter in the soil samples from Laukaa.

\begin{tabular}{|c|c|c|c|c|c|c|c|}
\hline \multirow{2}{*}{$\begin{array}{l}\text { Number } \\
\text { of } \\
\text { sample }\end{array}$} & \multirow[b]{2}{*}{ Kind of soil } & \multirow[b]{2}{*}{$\mathrm{pH}$} & \multirow{2}{*}{$\begin{array}{c}\text { Exchange- } \\
\text { able } \mathrm{CaO} \\
\%\end{array}$} & \multirow{2}{*}{$\begin{array}{c}\text { "Available" } \\
\mathrm{P}_{2} \mathrm{O}_{5} \\
\text { ppm }\end{array}$} & \multirow{2}{*}{$\begin{array}{c}\text { Tot. } \\
\mathrm{N} \\
0 / 00\end{array}$} & \multicolumn{2}{|c|}{ Azotobacter in } \\
\hline & & & & & & $\begin{array}{c}\text { fresh } \\
\text { samples }\end{array}$ & $\begin{array}{l}\text { enriched } \\
\text { samples }\end{array}$ \\
\hline L 1 & Carex-peat & 4.76 & 5.0 & 68 & 7.8 & & \\
\hline L 2 & $"$ & 4.75 & 12.6 & 38 & 7.0 & & \\
\hline L 3 s & Sandy mull & 6.40 & 4.5 & 102 & 3.4 & + & + \\
\hline L 4 & Silt & 5.70 & 2.9 & 49 & 2.1 & & \\
\hline L 5 & $"$ & 5.90 & 3.5 & 91 & 2.8 & + & + \\
\hline $\mathrm{L} \quad 6 \quad 1$ & Finesand mull & 6.30 & 3.3 & 81 & 2.3 & & + \\
\hline L 71 & Finesand & 6.33 & 3.1 & 15 & 1.7 & $(+)$ & + \\
\hline L 8 & " & 6.20 & 4.5 & 108 & 3.8 & & \\
\hline L 9 & 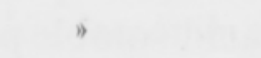 & 6.28 & 3.2 & 30 & 3.6 & & + \\
\hline L 10 & " & 6.20 & 3.1 & 50 & 1.9 & $=$ & + \\
\hline L 11 & Silt & 6.35 & 3.6 & 102 & 2.8 & & + \\
\hline L 12 & Finesand & 5.40 & 1.4 & 7 & 1.8 & & \\
\hline L 13 & Silt & 5.60 & 1.9 & 5 & 3.0 & & + \\
\hline L 14 & $\Rightarrow$ & 5.83 & 1.9 & 5 & 2.1 & $(+)$ & + \\
\hline L 15 & " & 5.84 & 2.3 & 8 & 2.0 & & \\
\hline L 16 & $B$ & 7.82 & 6.8 & 14 & 2.0 & & \\
\hline L 17 & Finesand & 5.85 & 2.7 & 18 & 3.6 & & \\
\hline L 18 & Carex-peat & 5.01 & 5.2 & 28 & 7.2 & & \\
\hline L 19 & Silt & 6.28 & 3.1 & 6 & 2.5 & & \\
\hline $\mathrm{L} 20$ & Finesand & 5.15 & 2.1 & 6 & 2.5 & & 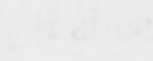 \\
\hline L 21 & Carex-peat & 5.50 & 3.8 & 4 & 4.4 & & \\
\hline L 22 & $"$ & 5.20 & 4.9 & 9 & 7.0 & & \\
\hline L 23 & Silt & 6.21 & 3.5 & 36 & 2.8 & & \\
\hline L 24 & Finesand & 6.32 & 2.8 & 11 & 2.4 & & \\
\hline L 25 & Sandy mull & 6.10 & 4.4 & 82 & 3.0 & + & + \\
\hline
\end{tabular}

These values do not markedly change, if the samples that gave positive tests after the enrichment are transferred into the first group.

Consequently, low contents of exchangeable calcium or "available" phosphorus, seem not to be the only factors responsible for the lack or low numbers of Azotobacter in these soils. No attention must be paid to the higher limit of the nitrogen content for the soils in which Azotobacter was absent, because these samples richest in nitrogen were from peat soils. Only the difference in the lower $\mathrm{pH}$ limits seems to be of importance. The acidity, probably, is also the main reason for the lack of Azotobacter in the peat soils tested.

Yet, the phosphorus status of the soil may have some influence upon the development of Azotobacter. Anyhow, the results of tests for the deficiency of calcium carbonate, potassium and phosphates in some of these soils indicate that the lack of available phosphorus prevents or retards the growth of inoculated Azotobacter in most soils. Following results were obtained: 


\begin{tabular}{|c|c|c|c|c|c|c|c|}
\hline \multirow{2}{*}{ Sample } & \multicolumn{3}{|c|}{$\begin{array}{l}\text { Acetic acid } \\
\text { soluble } \mathrm{P}_{2} \mathrm{O}_{5}\end{array}$} & \multicolumn{3}{|c|}{ Treatment } & \\
\hline & & ppm & 0 & $\mathrm{Ca}$ & CaK & $\mathrm{CaP}$ & CaPK \\
\hline L 6 & 6.30 & 81 & + & + & + & ++ & ++ \\
\hline L 8 & 6.20 & 108 & 0 & + & + & ++ & +++ \\
\hline L 11 & 6.35 & 102 & 0 & 0 & 0 & +++ & +++ \\
\hline L 10 & 6.20 & 50 & 0 & 0 & 0 & + & ++ \\
\hline L 16 & 7.82 & 14 & 0 & 0 & 0 & ++ & +++ \\
\hline L 17 & 5.85 & 18 & 0 & 0 & 0 & ++ & +++ \\
\hline L 23 & 6.21 & 36 & 0 & 0 & 0 & ++ & $+1+$ \\
\hline
\end{tabular}

None of these soils could develop any abundant growth of Azotobacter without applied phosphates, and only the soils containing very high amounts of acetic acid soluble phosphorus were able to support a scanty flora from their indigenous sources. The treatment with potassium was effective only in connection with phosphorus.

If there were any evidence that the amount of acetic-acid soluble phosphorus in a soil really indicates its content of plant available phosphorus, it could be claimed that Azotobacter requires a higher concentration of phosphorus than the crop plants. On the basis of 150 field experiments it was found that, generally these cultivated mineral soils did not respond to phosphorus fertilizers if their content of acetic acid soluble phosphate was about $20 \mathrm{ppm}$ (12). Thus, a soil in which inoculated Azotobacter develops without phosphate applications must be very rich in plant available phosphorus.

It is possible that the ability of Azotobacter to utilize the phosphorus compounds of our soils is poor, and that there really is the question of the lack of available phosphorus. However, the high need of soluble phosphates by this organism may be explained on the basis of other reasons, too. In his paper BRENNER (2) came to the conclusion that iron compounds of the soil can prevent the development of inoculated Azotobacter in some cases in spite of the application of calcium carbonate to the cultures. KRückowa and Popowa (14) also point to the injurious influence of soluble iron upon the growth of Azotobacter in soils rich in iron. Thus the favourable effect of applications of soluble phosphates upon the development of Azotobacter may be due to the fact that phosphates are needed to precipitate the harmful iron in the neighbourhood of the bacteria.

Some preliminary experiments performed in order to study the effect of iron and aluminium ions upon the development of Azotobacter chroococcum in mannitol solution cultures indicated that aluminium can be more dangerous than iron. The concentrations of aluminium, ferrous and ferric iron varied from 0.0025 to $2.5 \mathrm{ppm}$ in these cultures. Not even the highest amounts of ferrous or ferric iron did markedly prevent the growth of Azotobacter, but only the lowest concentrations of aluminium allowed the formation of a rather good Azotobacter-film.

The sensibility of Azotobacter chroococcum to soluble aluminium has been reported e.g. by KATZneLson (13). It is highly probable that the primary reason for the favourable influence of both liming and phosphorus fertilization upon the development of Azotobacter is to be found in the decrease in the injurious aluminium concentration of soil solution. 
The lack or the extremely low numbers of Azotobacter chroococcum in acid soils may largely be connected with the inability of this organism to tolerate the concentrations of aluminium and iron in these soils. The limiting $\mathrm{pH}$-value in the present investigation was about the same as generally reported or $\mathrm{pH} 5.8(9,11,15$ etc.). On the other hand, there are in the literature results that are in accordance with those obtained by Svinhufvud (25): Azotobacter chroococcum has been found from soils even more acid than of $\mathrm{pH} 5(1,16,27)$.

Several factors have been suggested to explain the fact that Azotobacter-tests can be negative also in soils with a high $\mathrm{pH}$ value. The deficiency in available molybdenum in the soil is supposed by van NIEL (17) to be the main reason in some cases. GAINEY (10) has found that some fertile soils contain nitrate nitrogen in such concentrations that the number of Azotobacter is highly decreased. Azotobacter is also very sensitive to high salt concentrations in general (6), and it is possible that in some soils this factor inhibits the development of this organism.

Yet, the most important cause for the low numbers of Azotobacter cells in nearly all the soils is to be found in the lack of available carbon compounds. This was emphasized already by REMY (19), and probably the competition for available energy is a more effective factor than the purely antagonistic influence of several soil microorganisms upon azotobacters.

No colonies that could be identified as Azotobacter indicum developed on the agar plates from the soil samples. Yet, it is quite possible that by prolonged investigations and by some other technique this acid tolerant species could be found also in our soils.

All the seventy two soils tested for the presence of Clostridium gave positive results. However, these tests did not show whether the organisms were present in the soils only as spores or also as living cells.

\section{Nitrogen fixation by the soil flora}

The increase in total nitrogen content of mannitol nutrient solutions inoculated with soil suspension does not give any reliable idea of the nitrogen fixing power of the soil in question. Yet, some relative values may be obtained, and characteristic differences between the soil populations found. In order to study the effect of the presence of Azotobacter chroococcum upon the nitrogen yields, nitrogen-free mannitol nutrient solutions inoculated with suspensions from 30 soils were incubated at $25{ }^{\circ} \mathrm{C}$ for three weeks.

Unfortunately there were no possibilities to arrange the experiments under conditions in which the absorption of nitrogen oxides or ammonia from the atmosphere would have been prevented. It was attempted to diminish this defect by the incubation of several control cultures.

The data in Table 2 indicate that the highest nitrogen yields were obtained in the cultures of the samples A 6, L 3 and L 5 which were found to contain Azotobacter rather abundantly. In almost all the other cultures the increase in nitrogen was considerably lower, In general, there seemed to exist a marked correlation between 
Table 2. Increase in the nitrogen content of mannitol solution cultures inoculated with soil suspension and incubated for three weeks.

\begin{tabular}{|c|c|c|c|c|c|}
\hline $\begin{array}{l}\text { Number } \\
\text { of } \\
\text { sample }\end{array}$ & Place & Kind of soil & $\mathrm{pH}$ & $\begin{array}{c}\text { "Available" } \\
\mathrm{P}_{2} \mathrm{O}_{5} \\
\text { ppm }\end{array}$ & $\begin{array}{c}\text { Increase } \\
\text { in } \mathrm{N} \\
\mathrm{mg}\end{array}$ \\
\hline
\end{tabular}

A 6 Kauhajoki

Clay

Cultivated soils

L 3 Laukaa

L 5

A 20

6 Tikkurila

A 7 Kokemäki

A 5 Perho

L 2 Laukaa

9 Karjalohja

1 Tikkurila

2 "

$\begin{array}{rc}3 & " \text { A } \\ 14 & \text { Liminka } \\ 20 & \text { Pulsa } \\ 19 & " \\ 18 & "\end{array}$

L 4 Laukaa

L 1

7 Karjalohja

\begin{aligned} 8 & \multicolumn{1}{c}{} \\ A 28 & Parikkala \\ A 15 & Sotkamo \\ A 23 & Merikarvia \\ 4 & Tikkurila \end{aligned}

$\begin{array}{lc}5 & \text { Tikkurila } \\ 10 & \text { Karjalohja } \\ 22 & \text { Pulsa } \\ 21 & \text { " } \\ 12 & \text { Karjalohja } \\ 11 & \end{array}$

Sandy mull

Silt

")

Clay

"

Silt

Carex-peat

Clay

Sandy mull

Clay

Mull

Clay

Carex-peat

Silt

Sand

Silt

Carex-peat

Sandy mull

Clay

Carex-peat

Clay mull

Carex-peat

Forest soils

Sand
Carex-peat
Sand
Moraine

$\begin{array}{lr}6.58 & 102 \\ 6.40 & 91 \\ 5.90 & - \\ 5.00 & - \\ 5.70 & - \\ 6.95 & - \\ 5.50 & 38 \\ 4.75 & 2 \\ 5.68 & 59 \\ 6.00 & 19 \\ 6.19 & 26 \\ 5.60 & - \\ 5.98 & 5 \\ 5.43 & 23 \\ 6.23 & 14 \\ 5.90 & 49 \\ 5.70 & 68 \\ 4.76 & 42 \\ 6.43 & 33 \\ 6.39 & - \\ 6.28 & - \\ 5.16 & - \\ 5.60 & - \\ 4.56 & \end{array}$

\begin{tabular}{rrr}
- & 7.6 \\
102 & 7.2 \\
91 & 6.9 \\
- & 6.5 \\
- & 4.7 \\
- & 4.6 \\
- & 4.6 \\
38 & 3.8 \\
2 & 3.5 \\
59 & 3.4 \\
19 & 3.4 \\
26 & 3.2 \\
\hline & 2.9 \\
5 & 2.5 \\
23 & 2.4 \\
14 & 2.3 \\
49 & 2.1 \\
68 & 1.9 \\
42 & 1.7 \\
33 & 1.1 \\
- & 0.8 \\
\hline & 0.8 \\
\hline 3 & 0 \\
& & 0
\end{tabular}


for the nitrogen yields in the present experiments as well as in BRENNER's works can be some of the numerous species of molds, yeasts and bacteria reported to be able to utilize atmospheric nitrogen $(4,8,21,22,23$, etc.), or the nitrogen fixation could be due to the activity of the Clostridium species found in all the samples tested in the present investigation.

The fact that most of the soil microorganisms fail to fix atmospheric nitrogen in pure cultures under laboratory conditions does not prove that they are unable to do that in soil associations. On the contrary, it is difficult to understand why only Azotobacter, Clostridium, and some of the Algae would possess this ability. Apparently microorganisms that can fix free nitrogen under certain conditions live in our soils, and probably this fixation requires associative growth and activity of several species. But has this phenomenon any significance in nature is another thing that depends on the supply of available energy and nutrients.

\section{Sum $m$ ar $y$}

In the present paper some observations upon the occurence of Azotobacter chroococcum in Finnish soils are reported. Without enrichment Azotobacter could be cultivated on the agar plates only from 5 soils out of the 72 samples tested. The enrichment procedure markedly increased the number of soils that gave positive results in the test. Azotobacter could not be found in soils with a $\mathrm{pH}$ value lower than 5.8. On the basis of the results it is concluded that Azotobacter probably is present in a large amount of our less acid soils, although generally, in very low numbers.

The phosphorus status of the soil exerted some influence upon the development of inoculated Azotobacter in soil plaques. In soil tests the phosphorus requirement of Azotobacter appeared to be markedly higher than that of the crop plants, in general. It was supposed that in some cases this fact could be explained not only on the basis of the phosphorus need of the bacteria but on the basis of the high sensitivity of the organism to the effects of soil aluminium and iron prevented by phosphates.

The cultivation of Azotobacter indicum from the soils failed, but Clostridium species could be found in all the samples tested.

The increase in the nitrogen content of the mannitol solution cultures during incubation was highest when the soil contained Azotobacter chroococcum. But also in several cultures of soils from which no Azotobacter could be found by the agar plate method, a considerable increase in nitrogen was observed. This was connected with the formation of a thick membrane of fungi and bacteria on the surface of the liquid. The possibility of nitrogen fixation by the associations of soil microorganisms is discussed.

\section{Acknowledgement}

The author wishes to express her gratitude to Prof. Unto Vartiovaara for placing the equipments of the Department of Microbiology at her disposal, and to Mr. Pentti Hänninen B. Agr. for the soil samples from the Laukaa farm. 


\section{REFERENCES}

(1) Altson, R. A. 1936. Studies on Azotobacter in Malayan soils. Soil Scil, 26, p. 268-280.

(2) Brenner, W. 1924. Azotobacter in finnländischen Böden. Agrogeol. Julk., 20. 15 pp. Helsinki.

(3) — - 1927. Über Stickstoffbindung durch frei lebende Mikroorganismen im Boden. Proc. First Int. Cong. Soil Sci., 3, p. 118-124.

(4) Carter, E. G. and Greaves, J. D. 1928. The nitrogen fixing microorganisms of an arid soil. Soil. Sci., 26, p. $179-197$.

(5) Curie, I. H. 1931. A method for the study of Azotobacter and its application to fertility plot soils. Ibid., 32, p. $9-25$.

(6) Efendieva, S. A. 1944. (The determination of the salt content of soils by means of the Azotobacter test.) Mikrobiologica, 13, p. 147-154. Ref. Biol. Abs., 20, p. 1703, 1946.

(7) Fred, E. B. and Waksman, S. A. 1928. Laboratory manual of general microbiology. 154 pp. New York.

(8) FreI, H. 1942. Quantitative Untersuchungen über die Assimilation des elementaren Stickstoffs der Luft durch hautbildende Hefen. Zbl. Bakt. II, 104, p. 326-365.

(9) Gainey, P. L. 1927. The occurrence of Azotobacter in soil. Proc. First. Int. Cong. Soil. Sci., 3, p. $107-117$

(10) — 1936. The tolerance of nitrate by pure cultures of Azotobacter. Ibid., 42, p. 445-459.

(11) Jensen, H. L. 1950. Om forekomst af Azotobacter i dyrkede jorder. Tidsskrift f. Planteavl, 53 , p. $622-649$.

(12) Karla, A. 1949. Maan fosforintarpeen määrittämisestä (On testing soils for phosphorus deficiency). Rep. State Agric. Res., 220, 26 pp. Helsinki.

(13) Katznelson, H. 1940. Survival of Azotobacter in soil. Soil Sci., 49, 21 - 35.

(14) Krǘcкowa, A. P. and Popowa, E. W. 1935. (Die Wirkung des Eisengehalts im Boden auf die Entwicklung des Azotobacters). Mikrobiologica, 4. p. 603-610. Ref. Zbl. Bakt. II, 97, p. 163, $1937-38$.

(15) Martin, W. P., Walker, R. H., and Brown, P. E. 1937. The occurence of Azotobacter in Iowa soils and factors affecting their distribution. Iowa State Col., Agr. Exp. Sta. Res. Bul., 217 , p. $225-256$.

(16) McKnight, T. 1949. Non-symbiotic nitrogen-fixing organisms in Queensland soils. Queensland J. Agr. Sci., 6, p. 177-195.

(17) VAn Niel, C. B. 1935. A note on the apparent absence of Azotobacter in soils. Arch. Mikr., 6, p. $215-218$.

(18) Norman, A. G. 1946. Recent advances in soil microbiology. Soil Sci. Soc. Amer. Proc., 11, p. 9 - 15.

(19) Remy, TH. 1909. Untersuchungen über die Stickstoffsammlungsvorgänge in ihrer Beziehung zum Bodenklima. Cbl. Bakt. II 22, p. 561-651.

(20) Sackett, W. G. and Stewart, L. C. 1931. A bacterial method for determining mineral soil deficiencies by use of the soil plaque. Colo. Agr. Exp. Sta. Bul., 375, p. 1-36.

(21) Schanderl, H, 1940. Über die Assimilation des elementaren Stickstoffs der Luft durch hautbildende Hefen und durch Cladosporium cellare. Zbl. Bakt. II, 101, p. 401-408.

(22) Selim, M. 1932. A study of nitrogen-fixing bacteria from soils. Proc. II Int. Cong. Soil Sci. Comm. III, p. $83-88$.

(23) Skinner, C. E. 1928. The fixation of nitrogen by Bacterium aerogenes and related species. Soil Sci., 25 , p. $195-205$.

(24) Stöckli, A. 1944. Die Verbreitung der Azotobacter-Organismen in der Schweiz. Landw. Jahrb. Schweiz, 58, p. $67-105$.

(25) Svinhufvud, V. E. 1937. Untersuchungen über die bodenmikrobiologische Unterschiede der Cajanderschen Waldtypen. Acta Forest. Fenn., 44, p. $1-67$.

(26) Tuorila, P. 1945. Några problem rörande kalkningsfrågan. Svenska Vall- o. Mosskulturför. Kvartalskr., 7, p. $83-101$.

(27) Wilson, J. K. and Wilson, B. D. 1933. The occurrence of Azotobacter in peat soils of New York. Cornell Univ. Agr. Exp. Sta. Mem., 148, p. 1-19. 
SELOSTUS:

HAVAINTOJA AZOTOBACTERIN ESIINTYMISESTÄ SUOMEN MAAPERÄSSÄ

ARMi KaILA

Yliopiston maanviljelyskemian laitos, Helsinki.

BRENNERin (2) ja Svinhufvudin (25) ristiriitaiset tulokset A zotobacter chroococcumin esiintymisestä Suomen maaperässä antoivat aiheen edellä olevaan tutkimukseen. Edellisen mukaan Azotobacter on meillä erittäin harvinainen, jälkimmäinen taas löysi sitä kaikista tutkimistaan happamistakin metsämaanäytteistä.

CURIEn (5) agar-malja menetelmää käyttäen todettiin Azotobacteria viidessä tutkituista 72 maanäytteestä. Rikastaminen muhittamalla pari viikkoa maata, johon oli sekoitettu kalkkia, mannitolia, fosfaattia ja hiven molybdaattia, lisäsi huomattavasti niiden näytteiden lukumäärää, joista kehittyi Azotobacter-pesäkkeitä. Kaikkien näiden $\mathrm{pH}$ oli vähintään 5.8. Tulokset viittaavat siihen, että Azotobacteria on verraten suuressa osassa lievästi happamia maitamme, vaikkakin tavallisesti hyvin niukasti.

Azotobacterin fosforin tarve näytti olevan melkoista suurempi kuin viljelyskasvien. Tämän oletettiin johtuvan joko siitä, että organismi pystyy huonosti käyttämään maan fosforiyhdisteitä, tai siitä, että liukenevien fosfaattien lisääminen on tarpeen sitomaan maassa Azotobacterille haitallisessa muodossa olevaa aluminiumia ja rautaa.

Suoritettujen kokeitten yhteydessä ei maanäytteistä onnistuttu viljelemään Azotobacter indicumia, mutta Clostridium-lajeja todettiin kaikissa näytteissä.

Kokonaistypen määrän lisääntyminen oli suhteellisesti suurin niissä mannitoli-liuos-viljelmissä, jotka oli siirrostettu Azotobacteria sisältävien näytteiden suspensiolla. Mutta myös useitten muitten maanäytteiden viljelmät sitoivat runsaanlaisesti typpeä. Näiden sekä BRENNERin (3) vastaavanlaisten havaintojen perusteella näyttää mahdolliselta, että monissa maissa on Clostridium-lajien lisäksi muita bakteereita, ehkä myös hiivoja ja homeita, jotka sekakasvustona pystyvät sitomaan ilmakehän vapaata typpeä. 